\title{
Öğretmenlerin Psikolojik Dayanıklılıkları İle İş Yaşam Kaliteleri Arasındaki İlişkinin Araştırılması ${ }^{1}$
}

\author{
DOI: 10.26466/opus.711430
}

\author{
Mustafa Yılmaz ${ }^{*}$ - Sinan Yalçın** \\ * Uzm. Psikolojik Danışman, MEB, Yozgat/Türkiye \\ E-Posta: yilmazmustafa.pdr@gmail.com \\ ORCID: $\quad 0000-0001-7686-5711$ \\ ${ }^{*}$ Doç. Dr., Erzincan Binali Yıldırım Üniversitesi Eğitim Fakültesi, Erzincan/Türkiye \\ E-Posta: sinan29@gmail.com \\ ORCID: $\quad$ 0000-0002-2372-9035
}

\section{Öz}

Bu araştırmada, öğretmenlerin psikolojik dayanıklılık düzeyleri ile iş yaşam kaliteleri arasındaki ilişki incelenmiştir. Araştırmada nicel araştırma yöntemi kullanılmıştır. Araştırma, iki ya da daha fazla değiişkenler arasındaki değişimin varlığını ya da var olan durumların belirlemeyi amaçlayan ilişkisel tarama modelinde tasarlanmıştır. Araştırmanın çalışma grubunu 2018-2019 eğitim öğretim yılında Yozgat-Merkez-Sorgun-Yerköy ilçelerinde bulunan resmi ilkokul, ortaokul ve liselerde görev yapmakta olan toplam 438 öğretmen oluşturmaktadır. Bu öğretmenlerin 244'ü (\% 55,7) erkek, 194 (\% 44,3) 'ü kadın öğretmenlerden oluşmaktadır. Araştırmada veri toplama araçları olarak, Psikolojik Dayanıklılık Ölçeği (PDÖ), İş Yaşam Kalitesi Ölçeği (IYYOÖ) ve Kişisel Bilgi Formu kullanılmıştır. Araştırmadan elde edilen verilerin analizinde Korelasyon Analizi ve Çoklu Regresyon Analizi yöntemleri uygulanmıştır. Araştırmadan elde edilen sonuçlara göre; öğretmenlerin psikolojik dayanıklılıklar ile okulda geçirdikleri hizmet süreleri arasında anlamlı bir farklılık ortaya çımıştır. Öğretmenlerin psikolojik dayanıklılık düzeyleri ile cinsiyet, branş, kıdem, öğrenim durumu ve okul türü değişkenleri arasında ise anlamlı bir farklılık çıkmamıştır. Öğretmenlerin psikolojik dayanıklılık düzeyleri ile iş yaşam kaliteleri arasında pozitif yönde anlamlı bir ilişki ortaya çıkmıştır. Ayrıca öğretmenlerin iş yaşam kalitesi alt boyutlarından sadece Toplam Yaşam Alanı alt boyutu öğretmenlerin psikolojik dayanıklllı düzeylerinin yaklaşık \%13'ünün anlamlı bir yordayıcısı olduğu tespit edilmiştir.

Anahtar Kelimeler: İş Yaşam Kalitesi, Öğretmen, Psikolojik Dayanıklılı.

\footnotetext{
${ }^{1}$ Bu çalışma 1. Yazarın 2. Yazar danışmanlığında yapmış olduğu tez çalışmasından üretilmiştir.
} 


\title{
Research On The Relation Between Worklife Quality And Psychological Hardiness Of Teachers
}

\begin{abstract}
In this research, the relationship between the psychological hardiness and work-life quality of teachers is analysed, and the quantitative research method is used.The research is designed in a relational screening model (correlational survey model) that aims to determine the presence of the change between two or more variables or the situations (cases) between them. The study group of the research consists of 438 teachers working in official primary/secondary and high schools located in the Yozgat city center and Sorgun/Yerköy districts of Yozgat in the academic year 2018-2019. 244 (55,7\%) of these teachers are male and 194 (44,3\%) are female.In the research psychological hardiness scale (BRS), work-related quality of life scale (WRQL) and personal information form were used as data collection tools. In the analysis of the data obtained from the research correlation analysis and multiple recreation analysis methods were used.According to the results concluded from the research, there is a significant difference between the pyschological hardiness of the teacher and the period of the service they spent at school. There is a positive relationship between teachers' pyschological hardiness levels and work-life quality.Besides,only the Total Living Area sub-dimension of teacher's work-life quality sub dimensions was detected(found) to be an important predictor of nearly $13 \%$ of teachers' pyschological hardiness levels.
\end{abstract}

Keywords: Worklife quality of, Teacher, Psychological hardiness, 


\section{Giriş}

İnsan biyo-psiko-sosyal bir varlık olması diğer canlılardan farklı kılan önemli bir özelliğidir. İnsan sosyal yaşamı içerisinde sevdiği bir kişinin ani kaybı, işten çıkarılması veya işlerinin kötü gitmesi, önemli sağlık sorunları, aile yaşamında ki sıkıntıları yaşamını etkileyebilir. Yaşam içerisinde karşılaşılan bu gibi durumlar ile mücadelesinde yeterli güç ve hazırlığa sahip değil ise, sıkıntılar ile mücadelesinde kendini güçsüz ve çaresiz hissedebilir bunlar sonucunda da yaşamında boşluklar oluşabilir. Yaşanılan olay ne kadar kötü etkilerse etkilesin mücadele gücü olan kişiler olaylara daha farklı yaklaşabilir. Olaylar karşısında mücadele edebilen bireyler olaylar karşısında çözüm yollarına hızlı ulaşıp, sıkıntı yaratacağını düşündüğü olaylara aynı hızla müdahale edebilen kişilerdir. Bireyler karşılarına çıkan olumsuz yaşam koşulları karşısında mücadeleyi bırakmayacaklarına ve bu gibi olaylar ile mücadele ettikçe de kendilerini iyi hissederek daha fazla çok güç kazanacaklarına dair inançlarını "kendini toparlama gücü" (resilience) söylenebilir. "Kendini toparlama gücü" kavramı içinse dikkat edilecek en önemli iki özellik ise; psikolojik dayanıklılık ve sosyal destek kavramlarıdır (Terzi, 2008).

Walsh (2006) psikolojik dayanıklılığı, sıkıntılı duurmlar ile karşılaşıldığında güçlü bir şekilde mücadele edebilmeyi ve kriz durumlarında bireyin gelişimine katkı sunduğu ve dayanıklılı̆̆ını arttıran önemli bir dönem olduğunu ifade etmektedir. Grotberg (1995) ise dayanıklılı̆̆ı, hayatın içerisinde zorlu yaşam şartlarını üstesinden gelmeyi hatta bu gibi olayları kendi lehine çevirerek olaylar karşsısından daha da güçlü çıkabilmeyi sağlayan bir davranış olarak ifade etmiştir. Eğitim çalışanları okul ortamlarında farklı olaylar ile karşılaştığında dayanıklılık düzeyleri çalısma performanslarını dolaylıda olsa etki ettiği düşünülmektedir. Bu sebeple bu araştırma öğretmenlerin iş yaşamında karşılaştıkları olaylar karşısındaki davranışlarını incelemek olmuştur.

Öğretmenlerin okul ortamlarında karşılaştıkları; iş yükünün ağırlığı, okulun fiziki donanımı, iş stresinin yoğun olması, öğretmenden beklentinin fazla olması gibi olumsuzluklar ile mücadele edebilmeleri için psikolojik dayanıklılık düzeylerinin yüksek olması gerekmektedir. Öğretmenler bu gibi olaylar karşısında daha sakin ve yapıcı durması beklenmektedir. Bu durumların sağlanabilmesi için eğitimcilerin psikolojik dayanıklılık düzeylerinin yüksek 
olması için önlemler alınmalı ve karşılaştıkları stres faktörleri analiz edilerek tükenmişliklerini yenmeleri oldukça önemlidir (Sezgin, 2012, s.491-492).

İş yaşam kalitesi, çalışanların işlerine karşı olumlu düşünceleri, iş ortamlarında ki iyileştirmeleri, üretimdeki ürün çıktısı ve sosyal yaşantıyı içerisinde barındıran bir kavramdır (Aba, 2009). İş yaşam kalitesi, çalışma ortamlarını düzenleyerek çalışanların tempolarına, işten memnun olma durumlarına ve motivasyonlarına pozitif katkılar geliştirmeyi hedefleyen bir durum olarak ifade edilebilir.

Okul ortmalarıda birer işyeri olduğundan öğretmenlerin okul yaşam kaliteleri, daha genel manada 'yaşam kalitesi' kavramına dayanmaktadır. Yaşam kalitesini "Bireylerin kendi kültürleri ve değerler sistemi içinde kendi durumlarını algılayış biçimi" olarak tanımlayan Avcı ve Pala'ya (2004) göre yaşam kalitesi; "Kişinin fiziksel fonksiyonlarını, psikolojik durumunu, aile içindeki ve dışındaki sosyal ilişkilerini, çevre etkilerini ve inançlarını da kapsamaktadır". Bu bağlamda genel yaşam kalitesinin, yaşamın bütün yönlerine ilişkin genel bir olumlu bakışı ifade ettiği, okullarda birer iş yeri olduğuna göre iş yaşam kalitesi öğretmenlerin yaşamında önemli yer nokta olduğu ve eğitimin işleyişindeki bileşenlere karşı duyulan memnuniyeti ifade ettiği söylenebilir. İş yaşamkalitesi ile ilgili ülkemizde yapılan araştırmalar incelendiğinde; İsmetoğlu (2017) yaptığı bir araştırmada branş öğretmenlerinin çok kültürlü yeterlilik düzeyleri ile iş yaşam kalitesine yönelik algıları üzerine araştırmalarda buşunduğu görülmekte. Yalçın (2014) ise; Öğretmenlerin algilarına göre okul yöneticilerinin liderlik stilleri ile öğretmenlerin iş yaşam kalitesi ve örgütsel bağlılık düzeyleri arasındaki ilişkiyi ele aldığı görülmektedir. Son olarakta Erdem (2008) yaptığı bir diğer araştırmada ise "Ögretmenlere Göre Kamu Ve Özel Liselerde Yasamı Kalitesi Ve Örgütsel Baglılıkla iliskisi" iş yaşam kalitesi ile ilgili eğitim alanında yapılan başlıca çalışmalar olduğu söylenebilir. Alan taraması yapıldığında psikolojik dayanıklılık düzeyleri ile iş yaşam kalitesini araştıran ilk araştırma olacağı bu nedenle eğitim ortamında bu önemli iki kavram üzerine yapılacak çalışmalara öncü olacağ1 düşünülmektedir.

Öğretmenler okul ortamlarında kendilerinden beklenen çalışamaları ortaya koyabilmeleri iş yaşam kalitelerine bağlıdır. Öğretmenlerin çalışma alanlarında etkililiğini ve verimliliğini etkileyen birden fazla faktörden söz edilebilir. Bu faktörler;bireysel ve örgütsel faktörler olarak iki farklı grupta incelenebilir. Bireysel faktörler incelendiğinde; cinsiyet, medeni durum, yaş, eğitim 
düzeyi, hizmet süresi, işyerindeki statü, sosyo-kültürel çevre ve kişilik yapısı iken, Örgütsel faktörlerde; ücret, işyerinin fiziksel koşulları, iş ve işin niteliği, yönetim ve denetim, gelişme ve yükselme olanakları ve işyerinin sosyal ortamıdır (Tözün vd., 2008; Aksu vd., 2002). Bu nedenle araştırmada öğretmenlerin demografik yapıları olabildiğince fazla tutulmaya çalışılmış; branş, cinsiyet, eğitim durumu ve meslekteki hizmet süreleri araştırmanın başlıca demografik değişkenleri olarak belirlenmiştir.

Araştırmaya konu olan 'Psikolojik Dayanıklılık' ve 'İş Yaşam Kalitesi' kavramları alan taraması yapılarak incelendiğinde eğitim alanlarında yapılan araştırmalarda farklı kavramlar ile incelendiği görülmekte. Oysa eğitim ortamı bir iş yaşamıdır ve bu nedenle öğretmenlerin psikolojik dayanıklılık düzeylerini ne gibi durumlar etkilediği bilinmesi gereken bir alan olduğu düşüncesi ile bu iki kavramın etkileşimi merak edilmiştir. Bu durumlara ek olarak öğretmenlerin psikolojik dayanıklılık düzeyleri ile iş yaşam kalitelerini etkilediği düşünülen 4 farklı demografik yapı araştırılmak istenmiştir. Bunlar; cinsiyet, branş, eğitim durumu ve meslekteki hizmet süreleri olmuştur.

\section{Araştırmantn amact}

Araştırmanın amacı öğretmenlerin psikolojik dayanıklılık düzeyleri ile iş yaşamı kaliteleri arasındaki ilişkinin incelenmesidir. Bu amaçla aşağıdaki sorulara cevap aranmıştır:

- Öğretmenlerin psikolojik dayanıklılıkları ne düzeydedir?

- Öğretmenlerin iş yaşam kaliteleri ne düzeydedir?

- Öğretmenlerin psikolojik dayanıklılıkları ile iş yaşam kalitesi düzeyleri arasında istatistiksel olarak anlamlı bir ilişki var mıdır?

- Öğretmenlerin iş yaşam kaliteleri ile psikolojik dayanıklılıklarını istatistiksel olarak anlamlı bir yordayıcısı mıdır?

\section{Yöntem}

$\mathrm{Bu}$ araştırmada öğretmenlerin psikolojik dayanıklılıkları ile iş yaşam kaliteleri arasındaki ilişkinin incelenmesi hedeflendiğinden, nicel araştırma yöntemi kullanılmıştır. Bu nedenle çalışmanın modeli ilişkisel tarama modeli olarak belirlenmiştir. İlişkisel Tarama Modeli, araştırmalarda değişkenler arası 
ilişki durumunun belirlenmesinde kullanılır (Şimşek, 2012, s.92). Bu yöntemde ki hedef, araştırmalarda ilişki durumlarının varlığını ve/veya ölçüsünü ortaya çıkarmaktır (Karasar, 2005, s.81).

\section{Çalışma Grubu}

Araştırmanın evreni 2018-2019 eğitim-öğretim döneminde Yozgat Merkez ilçesi olmak üzere Sorgun ve Yerköy ilçelerinide içine alan resmi ilkokul, ortaokul ve ortaöğretimlerde çalışan öğretmenler kapsamaktadır. Bu çalışmanın örneklemini ise, evrende bulunan eğitim çalışanları arasından basit tesadüfi örneklem yöntemi ile seçilen toplam 438 öğretmen oluşturmaktadır. Araştırmada katılımcılara ait bilgiler aşağıda verilmiştir.

Tablo 1. Araştırmaya Katılan Öğretmenlerin Demografik Bilgileri

\begin{tabular}{|c|c|c|c|}
\hline & Seçenekler & $\mathbf{N}$ & $\%$ \\
\hline \multirow{3}{*}{ Cinsiyet } & Erkek & 244 & 55,7 \\
\hline & Kadın & 194 & 44,3 \\
\hline & Toplam & 438 & 100 \\
\hline \multirow{3}{*}{ Eğitim Durumu } & Lisans & 386 & 88,1 \\
\hline & Lisans Üstü & 52 & 11,9 \\
\hline & Toplam & 438 & 100 \\
\hline \multirow{3}{*}{ Branş } & Sinif & 71 & 16,2 \\
\hline & Branş & 367 & 83,8 \\
\hline & Toplam & 438 & 100 \\
\hline \multirow{6}{*}{ Kidem } & $1-5$ & 165 & 37,7 \\
\hline & $6-10$ & 112 & 25,6 \\
\hline & $11-15$ & 72 & 16,4 \\
\hline & $16-20$ & 48 & 10,9 \\
\hline & $21-$ & 41 & 9,4 \\
\hline & Toplam & 438 & 100 \\
\hline \multirow{4}{*}{ Okul Türü } & İlkokul & 86 & 19,6 \\
\hline & Ortaokul & 149 & 34,1 \\
\hline & Lise & 203 & 46,3 \\
\hline & Toplam & 438 & 100 \\
\hline \multirow{5}{*}{$\begin{array}{l}\text { Hizmet } \\
\text { Süresi }\end{array}$} & $1-3$ & 279 & 63,7 \\
\hline & $4-6$ & 94 & 21,5 \\
\hline & $7-10$ & 45 & 10,3 \\
\hline & $11-$ & 20 & 4,5 \\
\hline & Toplam & 438 & 100 \\
\hline
\end{tabular}

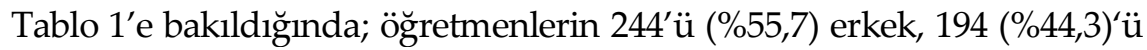
kadınlardan oluşmaktadır. Eğitim durumu değişkeninde ise; öğretmenlerin 
386'i (\%88.1) lisans mezunu, 52'si (\%11.9) lisans üstü mezunudur. Öğretmenlerin branş dağılımları; öğretmenlerin 71'i $(\% 16,2)$ sınıf öğretmeni, 367'si ise $(\% 83,8)$ branş öğretmeni olarak çalışmaktadır. Öğretmenlerin kıdem değişkenleri; 165'i (\%37,7) 1-5 yıl, 112'si (\%25,6) 6-10 y1l, 72'si (\%16,4) 11-15 yıl, 48'i (\%10,9) 16-20 yıl, 41'i (\%9,4) 20 yıl ve üzeri çalışma kıdemine sahiptirler. Öğretmenlerin okul türleri; 86'sı $(\% 19,6)$ ilkokulda, 149'u (\%34,1) ortaokulda, 203'ü ise $(\% 46,3)$ liselerde çalışmaktadır. Öğretmenlerin görev yaptığı okuldaki hizmet süreleri; 279'u (\%63,7) bulundukları okulda 1-3 yıl, 94'ü (\%21,5) 4-6 yıl, 45’i (\% 10,3) 7-10 yıl, 20'si (4,5) 11 yıl ve üzeri çalışma sürelerine sahiptirler.

\section{Verilerin toplanması}

Araştırmanın uygulanması, Yozgat İl Milli Eğitim Müdürlügünden alınan izin ile belirlenen Yozgat-Merkez-Sorgun-Yerköy ilçelerinde uygulanmıştır. Araştırmada öğretmenler ile ilgili bilgi toplanılması amacıyla Kişisel Bilgi Formu hazırlanmıştır. Hazırlanan form içeriğinde öğretmenlerin cinsiyet, branş, okul türü ve kıdemleri için sorular bulunmaktadır. Araştırma için gerekli verilerin alınması amacıyla öğretmenlere uygulanmak üzere iki ölçme aracı belirlenmiştir. Bunlar; (1) İş Yaşam Kalitesi Ölçeği ve (2) Psikolojik Dayanıklılık Ölçeğidir.

Psikolojik dayanıklılık ölçeği: Öğretmenlerin psikolojik dayanıklılık düzeylerini ölçmek için Terzi (2016) araştırmasında 21 sorudan oluşan Psikolojik Dayanıklılık Ölçeği kullanılmıştır. Psikolojik Dayanıklılık Ölçeği, bireyin kendisi ve yaşamına dair inançlarını ortaya koyan 21 farklı sorudan ve üç farklı alt boyuttan oluşmaktadır. Bu ölçekte, doğrudan ifadeler yanısıra ters ifadeli sorularıda içermekte, 2 . ve 15 . soruları ters yönde puanlanmaktadır. Psikolojik Dayanıklılık Ölçeğin tamamı için Cronbach alpha güvenirlik katsayısı .76 dır.Bu açlışmada ise iç tutarlık katsayısı (Cronbach $\alpha$ ) ,84 olarak bulunmuştur. Ulaşılan bu sonuç ile ölçeğin psikolojik dayanıklılık kişilik özelliğini geçerli ve güvenilir şekilde ortaya koyduğu sonucuna ulaşılmıştır.

İş yaşam kalitesi ölçeği: Erdem (2008) yaptığ çalışmasında iş yaşam kalitesini yedi alt alan olarak çalışmıştır. Her bir alan içinse ölçeğin bir alt ölçeği olarak düşünmüştür. İş yaşamı kalitesi ölçeği, likert ve beşli dereceleme şeklinde hazırlanmıştır. İş yaşam kalitesi ölçeği, toplam 43 sorudan oluşmaktadır. Erdem (2008) yapılan araştırmada iş yaşam kalitesi ölçeğine ait bulunan 
cronbah alfa değerleri ,81-,88 değerleri arasında hesaplanmıştır. Bu araştırmada ise cronbah alfa değerleri; ,79-,92 değerleri arasında hesaplanmıştır. Ölçeğin geneline ait cronbah alfa güvenirlilik katsayısına bakıldığında ise ,96 olarak çıkmıştır. Bu sonuçlar kıyaslandığında iş yaşam kalitesi ölçeğine ait sonuçlar ile Erdem (2008) tarafından elde edilen sonuçlar arasında benzerlikler olduğu ifade edilebilir.

\section{Verilerin analizi}

Çalışmada ilk örneklem grubundan elde edilen veriler incelenmiş, gelişigüzel doldurulan eksik veya hatalı veriler tespit edilerek elenmiş geriye kalan veriler bilgisayarda depolanmış, araştırma için veri deposu hazır hale getirilmiştir.

Araştırma için toplanan bilgiler parametrik ya da non parametrik istatistikler için uygun olup olmadığına bakmak için normallik dağılımına ve grupların varyans eşitliğine (Levene F testi) bakılmıştır. Normal dağılım testine ilişkin sonuçlar Tablo 2'de aktarılmıştır.

Tablo 2. Normallik Testi Sonuçları

\begin{tabular}{lll}
\hline & Skewness & Kurtosis \\
\hline Psikolojik Dayanıklılık & $-1,07$ & 1,13 \\
\hline Top. Yaş. Alanı. &,- 283 &, 007 \\
\hline Güv. Ve Sağl. Yaşam Al. &,- 355 &,- 288 \\
\hline İş Gör. Kap. Gel. &,- 458 &,- 127 \\
\hline Sosyal Sorumluluk &,- 203 &,- 266 \\
\hline Sosyal Bütünleşme &,- 666 &,- 119 \\
\hline Demokratik Ortam &,- 741 &, 317 \\
\hline Uygun ve Adil Karşllı &,- 081 &,- 156 \\
\hline
\end{tabular}

Tablo 2'ye bakıldığında çıkan sonuçların +1.5 ve -1.5 arasında çıkması verilerin normal dağılım gösterdiği, parametrik istatistikler için uygun olduğna ulaşılmıştır (Tabachnick ve Fidell, 2013).

Psikolojik dayanıklılık ve iş yaşam kalitesi arasındaki ilişkiyi belirlemek için Pearson momentler çarpımı korelasyon analizi ve iki değişken arasında ki yordama düzeylerini belirlemek içinde çoklu regresyon analizi yapılmıştır. Parametrik koşulların sağlandığı sonucundan sonra araştırmanın amacı kapsamında psikolojik dayanıklılık ile iş yaşam kalitesi arasında ilişkilerin incelenmesi için Pearson momentler çarpımı korelasyon katsayısı analizi yapılmıştır. Araştırmada kullanılan verilerin analizi analizi için SPSS 23.00 paket programı tercih edilmişitir. 


\section{Bulgular}

Araştırmanın bu bölümünde araştırma sonucunda elde edilen bulgulara yer verilmiştir.

Tablo 3. Öğretmenlerin psikolojik dayanıklllk dïzeyleri

\begin{tabular}{llll}
\hline & N & $\bar{X}$ & Ss \\
\hline Psikolojik Dayanıklıık & 438 & 62,79 & 8,82 \\
\hline
\end{tabular}

Öğretmenlerin psikolojik dayanıklılık düzeylerine ilişkin veriler incelendiğinde psikolojik dayanıklılığa ilişkin maddelere " $X=62,79$ " düzeyinde katıldıkları görülmüştür.

Öğretmenlerin psikolojik dayanıklılıklarna ve iş yaşam kalitelerine ilişkin betimsel istatistikler

Tablo 4. Öğretmenlerin İş Yaşam Kalitesi Düzeyleri

\begin{tabular}{llll}
\hline & $\mathbf{N}$ & $\bar{X}$ & Ss \\
\hline Toplam Yaşam Alanı & 438 & 13,91 & 3,65 \\
\hline Güvenli ve Sağlıklı Yaşam & 438 & 24,91 & 7,45 \\
\hline İş gören Kapasitesinin Geliştirilmesi & 438 & 20,86 & 6,40 \\
\hline Sosyal Sorumluluk & 438 & 23,71 & 7,50 \\
\hline Sosyal Bütünleşme & 438 & 19,37 & 5,07 \\
\hline Demokratik Ortam & 438 & 27,78 & 6,69 \\
\hline Uygun ve Adil Karşılık & 438 & 21,90 & 7,98 \\
\hline İş yaşam kalitesi toplam & $\mathbf{4 3 8}$ & $\mathbf{2 1 , 7 8}$ & $\mathbf{6 , 3 9}$ \\
\hline Psikolojik dayanıklılık toplam & $\mathbf{4 3 8}$ & $\mathbf{6 2 , 7 9}$ & $\mathbf{8 , 8 2}$ \\
\hline
\end{tabular}

Tablo 4 incelendiğinde öğretmenlerin iş yaşam kalitesi düzeylerine ilişkin ortalama ve standart sapma değerleri genellikle " $\bar{X}=21,78$ " düzeyde katıldıkları görülmüştür. İş yaşam kalitesinin yedi farklı alt boyutları tek tek incelendiğinde toplam yaşam alanı alt boyutuna öğretmenler " $\bar{X}=13,91$ ” düzeyinde, güvenli ve sağlıklı yaşam alt boyutunda öğretmenler, " $\bar{X}=24,91$ " düzeyinde, iş gören kapasitesinin geliştirilmesi alt boyutunda " $\bar{X}=20,86$ " düzeyinde, sosyal sorumluluk alt boyutu “ $\bar{X}=23,71$ " düzeyinde, sosyal bütünleşme boyutu " $\bar{X}=19,37$ " düzeyinde, demokratik ortam alt boyutu “ $\bar{X}$ $=27,78$ " düzeyinde, uygun ve adil karşıllk alt boyutu " $\bar{X}=21,90$ ” düzeyinde katıldıkları görülmektedir. 
Genel olarak bakıldığında öğretmenlerin iş yaşam kalitesi alt boyutları içerisinde en yüksek ortalama ( $\bar{X}=27,78$ ) ile "demokratik ortam alt boyutuolduğu bulnumuş, en düşük ortalamada ise $(\bar{X}=13,91)$ ile "toplam yaşam alanı" alt boyutu olduğu sonucuna ulaşılmıştır. Öğretmenlerin psikolojik dayanıklılık düzeylerine ilişkin ortalama ve standart sapma değerlerine bakıldığında öğretmenlerin psikolojik dayanıklılığa ilişkin sorulara genellikle “ $\bar{X}$ =62,79" düzeyinde katıldıkları görülmüştür.

\section{Öğretmenlerin Psikolojik Dayanıklılıklarn İle İş Yaşam Kalitesi Düzeyleri Arasındaki İlişki}

Tablo 5. Öğretmenlerin Psikolojik Dayanıklılık İle İş Yaşam Kaliteleri Arasındaki İlişki

\begin{tabular}{|c|c|c|c|c|c|c|c|c|}
\hline & 1 & 2 & 3 & 4 & 5 & 6 & 7 & 8 \\
\hline 1.Toplam yaşam alanı & 1 & - & - & - & - & - & - & - \\
\hline 2.Güvenli ve sağlıklı çalışma koşulları & $32^{* *}$ & 1 & - & - & - & - & - & - \\
\hline 3.İşgören kapasitesinin geliştirilmesi &, $36^{* *}$ & $67^{* *}$ & 1 & - & - & - & - & - \\
\hline 4.Sosyal sorumluluk & $30^{* *}$ & $69^{* *}$ &, $77^{* *}$ & 1 & - & - & - & - \\
\hline 5.Sosyal bütünleşme & $34^{* *}$ &, $52^{* *}$ &, $71^{* *}$ & $69^{* *}$ & 1 & - & - & - \\
\hline 6.Demokratik ortam & $32^{* *}$ &, $55^{* *}$ & $73^{* *}$ & $68^{* *}$ &, $85^{* *}$ & 1 & - & - \\
\hline 7.Uygun ve adil karşılık &, $30^{* *}$ & $41^{* *}$ & $45^{* *}$ & $42^{* *}$ & $39^{* *}$ & $42^{* *}$ & 1 & - \\
\hline 8.İş Yaşam Kalitesi Top. & $48^{* *}$ & $79^{* *}$ & $88^{* *}$ &, $86^{* *}$ & $83^{* *}$ &, $85^{* *}$ & $66^{* *}$ & 1 \\
\hline 9.Psikolojik Dayanıklılık Top. &, $32^{* *}$ & $24^{* *}$ &, $25^{* *}$ & $20^{* *}$ & $18^{* *}$ & $22^{* *}$ & $16^{* *}$ & $28^{* *}$ \\
\hline
\end{tabular}

${ }^{*} \mathrm{p}<0,05$ önem düzeyinde anlamlıdır ${ }^{* *} \mathrm{p}<0.01$ önem düzeyinde anlamlıdır.

Tablo.5 incelendiğinde psikolojik dayanıklılık ile iş yaşam kalitesi arasında $\mathrm{p}<0,01$ düzeyinde pozitif yönde anlamlı bir ilişki olduğu söylenebilir. İş yaşam kalitesinin alt boyutları açısından değerlendirildiğinde psikolojik dayanıklılık ile iş yaşam kalitesinin alt boyutları olan toplam yaşam alanı $(\mathrm{r}=, 32, \mathrm{p}<0,01)$ ile pozitif yönde, güvenli ve sağliklı yaşam $(\mathrm{r}=, 24, \mathrm{p}<0,01)$ ile pozitif yönde, iş gören kapasitesinin geliştirilmesi $(r=25, p<0,01)$ ile pozitif yönde, sosyal sorumluluk $(\mathrm{r}=, 20, \mathrm{p}<0,01)$ ile pozitif yönde, sosyal bütünleşme $(\mathrm{r}=, 18, \mathrm{p}<0,01)$ ile pozitif yönde, demokratik ortam $(\mathrm{r}=22, \mathrm{p}<0,01)$ ile pozitif yönde, uygun ve adil karşıllk $(r=, 16, p<0,01)$ ile pozitif yönde, toplam iş yaşam kalitesi $(r=28, p<0,01)$ ile pozitif yönde anlamlı bir ilişki olduğu görülmektedir. Bu sonuca göre öğretmenlerin psikolojik dayanıklılık düzeylerinin artmasının iş yaşam kalitelerini artıracağı söylenebilir. 


\section{Öğretmenlerin İş Yaşam Kalitelerinin Psikolojik Dayanıklılıkların} Yordaması

Tablo 6.Öğretmenlerin Psikolojik Dayanıklılık Düzeylerinin Yordamasına İlişkin Çoklu Doğrusal Regresyon Analizi Sonuçları

\begin{tabular}{llllll}
\hline Değişkenler & $\mathbf{B}$ & $\mathbf{S H b}$ & $\boldsymbol{\beta}$ & $\mathbf{t}$ & $\mathbf{p}$ \\
\hline Sabit & 44,077 & 2,568 & - & 17,165 &, 000 \\
\hline Toplam Yaşam Alanı & 3,174 &, 605 &, 259 & 5,248 &, 000 \\
\hline Güvenli ve sağlıklı çalışma koşulları &, 169 &, 109 &, 103 & 1,553 &, 121 \\
\hline İş gören kapasitesinin geliştirilmesi &, 170 &, 144 &, 098 & 1,185 &, 237 \\
\hline Sosyal sorumluluk &,- 060 &, 129 &,- 037 &,- 463 &, 643 \\
\hline Sosyal bütünleşme &,- 260 &, 182 &,- 127 & $-1,428$ &, 154 \\
\hline Demokratik ortam &, 224 &, 146 &, 140 & 1,539 &, 125 \\
\hline Uygun ve adil karşılık &, 008 &, 072 &, 006 &, 116 &, 908 \\
\hline
\end{tabular}

$\mathbf{R}=.36 \mathbf{R}^{2}=.13 \quad \mathbf{F}_{(7,430)}=9,405 \quad \mathrm{p}=.001$

Öğretmenlerin iş yaşam kalitesine ait değişkenlerine göre psikolojik dayanıklılıklarının yordanmasına dair regresyon analizlerine ait veriler Tablo $6{ }^{\prime}$ da sunulmuştur. Tablo 6'ya bakıldığında toplam yaşam alanının psikolojik dayanıklılığı anlamlı olarak yordadığı, iş yaşam kalitesinin diğer $6^{\prime} 1$ alt boyutunun ise psikolojik dayanıklılık düzeyini yordamadığ $(\mathrm{p}>.05)$ bulunmuştur.

Toplam yaşam alanı boyutu psikolojik psikolojik dayanıklılık düzeyindeki varyansın yaklaşık (" $R=.36$ " “ $R$ " =.13" $p<.01$ ) “\%13'ünü açıklamaktadır.

Standardize edilmiş regresyon katsayısına $(\beta)$ göre, yordayıcı değişkenlerin psikolojik dayanıklılık düzeyi üstünde ki göreli önem sırası ise; toplam yaşam alanı, demokratik ortam, güvenli ve sağlıklı çalışma koşulları, sosyal bütünleşme, iş gören kapasitesinin geliştirilmesi, sosyal sorumluluk, uygun ve adil karşılık şeklindedir.

\section{Sonuç}

Yaşam içerisinde bireylerin karşılaştıkları zorluklar ile mücadelesi yada hızla ilerleyen yaşamlarında değişimlere alışmak anlamına gelen psikolojik dayanıklılık zaman içerisinde önemi daha iyi anlaşılan bir kavram olmuştur. Bireylerin fiziksel güçlerinin modern dünyada yetmediği onların mutlu olabilmeleri için psikolojik dayanıklılıklarının güçlü olmaları gerekliliğini ortaya çıkarmıştır. Bu durum günümüzde psikolojik dayanıklılı̆̆ın daha çok konuşulmasına ve bu konu ile ilgili araştırılmaların çoğalmasına neden olmuştur. 
Hızla gelişen dünyada örgütler arasında oluşan rekabet, uzun soluklu ve sürdürülebilir bir büyüme elde etme süreci için etkinliliklerinde verimliliklerini arttirmak için olağan işleyişlerine ekstra çalışmalar yapmaktalar yeni uygulamalar ile örgütlerde verimliliği arttırmaya çalışmaktalar. Örgütlerde bu tarz çalışmalarda, örgütlerin işleyişinde ana unsurun insan olmasından dolayı insanlarda bilinmeyenlerinin keşfi ve bunların örgütsel davranış süreci içerisinde ruhsal ve duygusal kapsamlarında hem bireysel hemde örgütsel performansları çerçevesinde değerlendirme sürecine alınması gerekmektedir (Erdem vd, 2015, s.39; Biçkes vd., 2014, s.97). “Bu çalışmalar ışığında hızla değişim içerisinde olan iş dünyasında, psikolojik dayanıklılık seviyeleri yüksek olanların, değişime uyum sağlayan, yaratıcı,terslikler ve engeller karşısında yılmadan mücadele etmeleri performanslarının pozitif yönde etkileyeceği ortaya çıkmakta" (Çetin ve Basım, 2012, s.126) ve bu durumu da örgütlere çok iyi katkılar sunacağı düşünülmektedir.

Hızla ilerleyen teknolojik gelişmelere uyum sağlamaya çalışan en önemli örgüt kolu ise okullar olduğu kaçınılmaz bir gerçeklik olarak karşımıza çımaktadır. Özellikle bu durum hizmet kolunda olması bu alanda yapılacak her bir araştırmayı değerli kılmaktadır. Bunların başında öğretmenlerin iş yaşam kaliteleri ile psikolojik dayanıklılık düzeyleri arasında bir ilişki olduğu düşüncesi oluşturmaktadır. Bu kapsamda öğretmenlerin çalışma alanları olan okullarda oluşan değişkenler incelenmiş ve faklı sonuçlara ulaşılmıştır. Araştırma sonucunda elde edilen veriler ile aşağıdaki sonuçlara ulaşılmıştır.

Öğretmenlerin psikolojik dayanıklılık ile ilgili ifadelere $\bar{X}=62,79$ düzeyinde katıldıkları sonucuna ulaşılmıştır. Psikolojik dayanıklılık ölçeğinden alınan en yüksek puanın 126 olduğu düşünüldüğünde bu araştırma için öğretmenlerin psikolojik dayanıklılık düzeylerinin orta düzeyde olduğu ifade edilebilir. Karataş (2016), Yıldırım-Usta (2018) ve Yalçın (2013) tarafından yapılan araştırmalarda öğretmenlerin psikolojik dayanıklılık düzeylerinin orta düzey olduğu sonucuna ulaşılmıştır. Bu sonuç araştırma sonucunu desteklemektedir. Karakuş (2017), Kelekçi ve Yılmaz (2015), Tösten ve Özgan (2017), Çakmak ve Arabacı (2017), Sezgin Nartgün ve Mor (2015), Yıldırım ve Tösten (2019), Yalçın, Akan ve Yıldırım (2018) ve Uçar (2014) ise yaptıkları çalışmalarda öğretmenlerin psikolojik dayanıklılıklarının yüksek düzeyde olduğu sonucuna ulaşmışlardır. Bu sonuç araştırma sonuçları ile benzerlik gösterme- 
mektedir. Bu araştırmalarda yüksek düzeyde bir sonuca ulaşılmasında, örneklem olarak alınan öğretmenlerin; fiziki ortam, çalışllan kademe, yaş ortalamaları, eğitim düzeyleri, cinsiyetleri gibi değişkenler etkili olmuş olabilir.

Araştırma kapsamında ulaşılan bir diğer bulguya göre öğretmenlerin iş yaşam kalitesi düzeylerinin alt boyutlar açısından değerlendirildiğinde toplam yaşama alanı düşük, iş gören kapasitesinin geliştirilmesi, güvenli ve sağlıklı çalışma koşulları, sosyal bütünleşme, demokratik ortam alt boyutlarında genel olarak yüksek düzeydedir. Bu sonuç erdem (2010), Yalçın ve Akan (2016) tarafından yapılan araştırma sonuçları ile benzerlik göstermektedir. Demir (2016) yaptığı araştırmasında meslek lisesinde çalışan öğretmenlerin iş yaşam kalitelerini "orta" düzeyde olduğu aynı durumda Kösterelioğlu (2011) ilköğretim okulunda çalışan öğretmenlerin iş yaşam kalitesi düzeyini aynı şekilde "orta" düzeyde olduğu sonucunu bulmuş. İsmetoğlu (2017) yapılan bir diğer araştırma da da öğretmenlerin iş yaşam kalitelerinin "orta" düzeyde olduğu sonucuna ulaşılmıştır.

Okulu hedeflerine ulaştırmada ve verimli okulu oluşturmada öğretmenlerin üzerindeki yük önemli bir faktörü oluşturmaktadır. Bu nedenle öğretmenlerin okullarına bağlı kalması, okullarının kendileri için bir yaşam alanı gibi görmeleri, öğretmenlerin okulda mutlu rahat hissetmeleri, mutlu olabilmeleri, özetle iş yaşam kalitelerinin yüksek tutulması hedeflenen okul politikaları için öğretmenlerden beklenen performansın ortaya çıkmasını sağlayabilir. Araştırma sonucunda elde edilen bilgiler ışığında öğretmenlerin iş yaşam kalitesi puanlarının yüksek çıkması da çalışılan grubun okullarına karşı pozitif düşüncelerin fazla olduğu sonucu çıkarılabilir.

Araştırmada elde edilen bulgulara göre öğretmenlerin psikolojik dayanıklılık düzeyleri ile iş yaşam kalitesinin bütün alt boyutları ile arasında pozitif yönde anlamlı bir ilişki olduğu sonucuna ulaşılmıştır. Turan (2014) yaptı̆̆ bir araştırmasında, Psikolojik güçlendirme ve iş yaşam kalitesi arasındaki ilişkiyi bakmış; psikolojik güçlendirme düzeylerinin geliştirilmesinin iş yaşam kalitesi düzeyine arttırdığı bulgusuna ulaşmış.

Araştırma sonucunda ulaşlan bir diğer bilgide ise Öğretmenlerin psikolojik dayanıklılıkları üzerinde iş yaşam kalitesinin sadece toplam yaşam alanı boyutunun anlamlı bir yordayıcı olacağı şeklinde bir sonuç elde edilmiş. İş yaşamı, sosyal yaşamı her anlamda etkilemektedir. Örgütlerde yaşanılan olumsuz durumların sosyal yaşama ve boş zamana taşınması iş görenleri sürekli rahatsız etmektedir. Bir öğretmen iş yerinde endişelendiğinde ve yoğun 
strese girdiğinde, eve geldiğinde iş yerindeki stresli olayları düşünmeden edememektedir. Çalışma hayatında mutsuz olan bireyin evinde mutlu olmasını beklemek bir davranış değildir (Erdem, 2008). Toplam yaşam alanlarında öğretmenlerin mutlu ve huzurlu olması psikolojik dayanıklılıklarını olumlu etkileyeceği söylenebilir. Sosyal yaşantısında mutlu olan bireyin iş yaşamında da mutlu olabileceğini veya tersi durumda da yaşantılardaki duygu durumlarının etkilenebileceğini söyleyebiliriz. 


\title{
EXTENDED ABSTRACT
}

\section{Research On The Relation Between Worklife Quality And Psychological Hardiness Of Teachers}

\author{
Mustafa Yılmaz - Sinan Yalçın \\ Ministry of National Education-Erzincan Binali Yildırım Universty
}

Teaching is a profession that necessitates the communication channels to be open constantly. This case constrains education personnel excessively in a school environment and sometimes affects positively or negatively in the face of events. It is inevitable that all kinds of psychological factors that influence teachers, who carry out the education and training activities and, therewithal, are in continuous interaction with school administrators, students and parents, also affect the education process positively or negatively (Öztürk and Uzunkol, 2013). Various situations like this in education environments can demonstrate difference depending on teachers' psychological resilience in different situations. Psychological resilience personality traits consisting of three scopes as controlling, commitment and challenge. Controlling is the power of an individual to react against stressful and difficult situations, having the belief that they will affect the flow of events and change the events by analysing them well instead of feeling hopeless and unhappy. On the other hand, commitment is the fact that the individual is involved in ordinary events without being left out in existing events in an active state and attributing meaning to these events for a purpose. Challenge is that the individual accepts the security situation as a positive behaviour rather than as a threat in situations in which life changes are considered as usual (Sezgin, 2012). As it is referred the level of reactions teachers will demonstrate in case of different events in schools may depend on their psychological resilience. With this study, it is aimed to investigate the sort of relationship between teachers' resilience and their work-life quality. With this purpose, it is intended to examine the psychological resilience and work-life qualities of teachers in terms of some variables. These variables can be referred to as branch, year of the profession, education status and school types. Accordingly, these research questions were asked. 
- What is the psychological resilience levels of teachers?

- What are the work-life quality levels of teachers?

- Is there a statistically significant relationship between the psychological resiliences and work-life quality levels of teachers?

- Is the work-life quality of teachers a statistically significant predictor of their psychological resilience?

As it is aimed to investigate the relationship between the psychological resiliences of teachers and their work-life qualities, the quantitative research method was employed in this study. the model of the study was determined as the correlational survey method. The Correlational Survey Models are mostly used in determining the correlation between variables (Şimşek, 2012, p.92). The purpose of this method is to put forth the presence and/or extent of correlation status in the study (Karasar, 2005, p.81). The universe of the research consists of teachers in-service in state primary, secondary and high schools in Yozgat-City centre- Sorgun-Yerköy districts in 2018-2019 educational year. The sample of the research consists of 438 teachers selected with the simple random sampling method among the teachers in the universe.

According to the results of the research, as the average and standard deviation values related to the psychological resiliences levels of the teachers were analysed, it was noticed that the teachers agreed on the items relevant to the psychological resilience at the level of " $X=62,79$ "; as the average and standard deviation values of teachers related to their work-life qualities were analysed, it was found that they agreed on the items relevant to the work-life qualities of teachers at the level of " $=21,78$ ". As the relationship between the psychological resiliences of teachers and their work-life qualities were analysed, it can be stated that there was a positive significant correlation between the psychological resilience and work-life quality at the level of $p<0,01$. In Multiple Linear Regression Analysis Relevant to Predicting Psychological Resilience Levels of Teachers, it was found that total life area significantly predicted psychological resilience; however, safe and healthy working conditions, development of working capacity, social responsibility, social integration, democratic environment, appropriate and fair payout levels did not predict the psychological resilience level ( $\mathrm{p}>.05)$.

It was reached that the teachers agreed on the expressions relevant to the psychological resilience at the level of $=62,79$. As it is considered that the highest score from the psychological resilience scale was 126 , the psychological 
resilience levels of the teachers for this study can be referred to as moderate. In the studies conducted by Karataş (2016), Yıldırım-Usta (2018) and Yalçın (2013), they found that the psychological resilience levels of teachers were moderate. As the results of these researches were evaluated together with my research, it can be referred that results were supporting each other. In the studies by Karakuş (2017), Kelekçi and Yılmaz (2015), Tösten and Özgan (2017), Çakmak and Arabacı (2017), Sezgin Nartgün and Mor (2015), Yıldırım and Tösten (2019), Yalçın, Akan and Yıldırım (2018) and Uçar (2014), they found that the psychological resiliences of teachers were at high levels. These results did not demonstrate the similarity with the results of the present research. In reaching such high levels in these researches, the variables such as physical environment, the level of school worked at, age averages, education levels, genders of the teachers taken as the sample may have affected.

According to another result of the research, as the work-life quality levels of teachers were evaluated in terms of the sub-dimensions, it was found to be high in general at the level of total living area, safe and healthy working conditions, development of working capacity, social integration, democratic environment. This result demonstrates a similarity with the results of the researches conducted by Erdem (2010), Yalçın and Akan (2016). In other researches, while Demir (2016) determined that the work-life quality perceptions of the vocational high school teachers at "moderate level", similarly, Kösterelioğlu (2011) found the work-life quality perceptions of the primary school teachers at " moderate level". In another study by İsmetoğlu (2017), it was concluded that the work-life qualities of teachers were at a moderate level. As the field analysis was performed, it can be stated that the education environment is the work-life of teachers and further researches can be conducted by increasing the variables affecting the psychological resilience in this field.

There are some limitations to this study. These are the existence of more than one variable affecting educational environments and only gender, branch, year of the profession, educational status and school types to be taken into consideration in this study. It is believed that by increasing such studies related to the education personnel, further researches with different variables on teachers' psychological resilience and work-life quality will answer the question of how to work more efficiently in educational environments. 


\section{Kaynakça / References}

Aba, G. (2009). İş yaşam kalitesi ve motivasyon ilişkisi: Sağlık sektöründe bir uygulama. Yayımlanmamış Yüksek Lisans Tezi, Akdeniz Üniversitesi Sosyal Bilimler Enstitüsü, İşletme Anabilim Dall, Antalya.

Aydın, İ. (2002). Is şaşamında stres (2. Baskı). Ankara: Pegem Akademi Yayınları.

Balay, R. (2000). Özel ve resmi liselerde yönetici ve öğretmenlerin örgütsel bağhllı̆̆r: Ankara İli örneği. Yayımlanmamış Doktora Tezi, Ankara Üniversitesi Sosyal Bilimler Enstitüsü, Ankara.

Çakmak, M. S., ve Arabaci, İ. B. (2017). Öğretmenlerin pozitif psikolojik sermaye algilarının iş doyumları ve örgütsel bağllıkları üzerindeki etkisi. Electronic Journal Of Social Sciences, 16(62).

Çetin, F. ve Basım, H.N. (2012). Örgütsel psikolojik sermaye: Bir ölçek uyarlama çalışması. Amme İdaresi Dergisi, 45(1), 121-137.

Demir, T. (2016). Meslek lisesi öğretmenlerinin iş yaşam kalitesine ilişkin algilan ile örgütsel bă̆llık düzeyleri arasındaki ilişki.Yüksek Lisans Tezi, İstanbul.

Erdem, H., Yunus, G., ve Ufuk T. . (2015). Psikolojik sermayenin örgütselözdeşleşmeüzerine etkisinde algilanan örgütsel desteğin aracllk rolü. İsletme Araştırmalan Dergisi, 7(2), 38-62.

Erdem, M . (2010). Öğretmen algılarına göre liselerde iş yaşamı kalitesi ve örgütsel bağlllikla ilişkisi. Kuram Ve Uygulamada Ĕ̆itim Yönetimi , 4(4) , 511-537.

Erdem, M.(2008).Öğretmenlere Göre kamu ve özel liselerde iş yaşamı kalitesi ve örgütsel bağhlıkla ilişkisi. Doktora Tezi.Ankara Üniversitesi Eğitim Bilimleri Enstitüsü. Ankara

İsmetoğlu, M. (2017). Branşöğretmenlerinin çok kültürlü yeterlik düzeyleri ve iş yaşam kalitesine yönelik algıları.Yüksek Lisans Tezi.Aban İzzet Baysal Üniversitesi

Karasar, N., (2005). Bilimsel araştırma yöntemi. Ankara:Nobel Kitabevi. 310.

Karataş, R. (2016). Özel eğitim okullarında çalışan öğretmenlerin psikolojik dayanıklılk düzeyleri ve başa çıkma stratejilerinin incelenmesi. Hacettepe Üniversitesi, Eğitim Bilimleri Enstitüsü, Yüksek Lisans Tezi, Ankara.

Kelekçi, H., ve Yılmaz, K. (2015). Öğretmenlerin pozitif psikolojik sermayeleri ile yeterlik inançlanı arasındaki ilişki. Mersin Üniversitesi Eğitim Fakültesi Dergisi, 11(3).

Kösterelioğlu, M.(2011). İköğgretim okulu öğretmenlerinin iş yaşam kalitesi ile işe yabancılaşması arasındaki ilişki. Doktora Tezi.Abant İzzet Baysal Üniversitesi, Sosyal Bilimler Enstitüsü.Bolu

Luthans, F., Vogelgesang, G.R. ve Lester, P.B. (2006). Developing the psychological capital of resiliency. Human Resource Development Review, 5(1), 25-44.

Nartgün, Ş. S., ve Mor, K. D. (2015). Öğretmenlerin görüşlerine göre etik liderlik ve psikolojik dayanıklılı ilişkisi. Aibü Sosyal Bilimler Enstitüsü Dergisi, 15(2), 15 
Sezgin, F. (2012). Illköğretim okulu öğretmenlerinin psikolojik dayanıklllk düzeylerinin incelenmesi. Kastamonu Ĕ̈itim Dergisi, 20, 489-502.

Şimşek,A. (2012).Sosyal bilimlerde araştırma yöntemleri. Ed. A. Şimşek, Araştırma Modelleri, Anadolu Üniversitesi Açıköğretim Fakültesi Yayınlan, Eskişehir, 80-106.

Tabachnick, B, veFidell Ls. (2013). Using multivariate statistics. (Sixth Ed.), England:Pearson Education Limited.

Terzi, Ş. (2008). Üniversite öğrencilerinin psikolojik dayanıklllkları ve algladıkları sosyal destek arasındaki ilişki. Türk Psikolojik Damışma Ve Rehberlik Dergisi,3(29), 1-11.

Tösten, R. ve Özgan, H. (2017). Öğretmenlerin pozitif psikolojik sermayelerine ilişkin algilarmnn incelenmesi. Elektronik Sosyal Bilimler Dergisi, 16 (62)

Yalçı, S , Akan, D, ve Ylldırım, İ . (2018). Öğretmenlerin algılarına göre okul yöneticilerinin liderlik stilleri ile öğretmenlerin pozitif psikolojik sermaye düzeyleri arasındaki ilişkinin incelenmesi. Karadeniz Sosyal Bilimler Dergisi, 10(18)

Yalçın, S., ve Akan, D. (2016). Okul yöneticilerinin liderlik stilleri ile öğretmenlerin iş yaşam kalitesi ve örgütsel bağlllkkları arasındaki ilişkinin incelenmesi. Electronic Journal Of Social Sciences, 15(59).

Yalçin, S. (2013). İlköğretim okulu öğretmenlerinin mesleki tükenmiş̧lik düzeyleri ile stres, psikolojik dayaniklilik ve akademik iyimserlik arasindaki ilişki.Yüksek Lisans Tezi, Gazi Üniversitesi Eğitim Bilimleri Enstitüsü.

Yıldırım, İ., ve Tösten, R. (2020). Öğretmenlerin pozitif psikolojik sermaye algiları ile mesleki adanmışlkklarının incelenmesi. Dicle Üniversitesi Ziiya Gökalp Ĕ̈itim FaküItesi Dergisi, 36, 10-17.

Yıldırım-Usta, E. (2018). Hayatın anlam algisı ve psikolojik dayanıkllik düzeyi arasındaki ilişkinin analizi: İstanbul İli, Üsküdar İlcesi, resmi liselerde görev yapan öğretmenler örneğiYYayınlanmamış Yüksek Lisans Tezi, Nişantaşı Üniversitesi Sosyal Bilimler Enstitüsü

\section{Kaynakça Bilgisi / Citation Information}

Yılmaz, M. ve Yalçın, S.(2020). Öğretmenlerin psikolojik dayanıklılıkları ile iş yaşam kaliteleri arasındaki ilişkinin araştırılması. OPUS-Uluslararası Toplum Araştırmaları Dergisi, 16(Eğitim ve Toplum Özel Sayısı), 59555973. DOI: $10.26466 /$ opus.711430 